\title{
Chemical constituents, antioxidant, and antimicrobial activity of Allium chinense G. Don
}

\author{
Thejanuo Rhetso, R. Shubharani, M. S. Roopa and V. Sivaram*
}

\begin{abstract}
Background: Allium chinense G. Don is a medicinal and aromatic herb belonging to the family Amaryllidaceae, characterized by a high saponin content. The previous report has mostly been focused on the bulb, and there is very limited work on the leaf. The information about biological and chemical constituent of $A$. chinense leaf is still inadequate in contrast to the investigations reported on the bulb. To the best of our knowledge, there is no report on the hexane extract of both bulb and leaf extract. Therefore, the present investigation was focused on identifying and characterization of the hexane extracts of $A$. chinense bulb and leaf quantitatively and by using the GC-MS method and to know its scavenging, antibacterial, and antifungal activity.

Results: Twenty-eight bioactive compounds were identified in the bulb and nine in the leaf extract by GC-MS analysis. The versatile compounds present in the bulb are 2-methyloctacosane (21.30\%), tetracontane (14.05\%), eicosane, 10-methyl (12.06\%), heneicosane (8.46\%), octadecyl trifluoroacetate (6.48\%), and 1-heneicosanol (5.76\%), whereas in the leaf, it was phytol (35.76\%), tetratetracontane (18.49\%), perhydrofarnesyl acetone (14.76\%), and heptadecane, 2,6-dimethyl (10.79\%). In quantitative estimation, saponins were estimated to have the highest with $375.000 \pm 0.577 \mathrm{mg} / \mathrm{g}$ in the leaf and $163.750 \pm 0.433 \mathrm{mg} / \mathrm{g}$ in the bulb. The DPPH antioxidant scavenging activity was found to be minimum in both the bulb $\left(I C_{50}=678.347 \mu \mathrm{g} / \mathrm{ml}\right)$ and leaf $\left(I C_{50}=533.337 \mu \mathrm{g} / \mathrm{ml}\right)$. A. chinense extracts of both leaf and bulb exerted potential antibacterial effects against Staphylococcus aureus and Pseudomonas aeruginosa. Leaf extract exhibited greater antifungal activity than the bulb against Aspergillus niger.

Conclusion: From the analysis, the hexane leaf extract exhibited higher antibacterial, antifungal, and antioxidant activity than the bulb. Their superior activity might be due to the higher content of total saponin and terpenes. This result will lead to further in-depth research towards the potential use of this plant; the bio-constituents can be further isolated and used in medical and therapeutic applications.
\end{abstract}

Keywords: Bulb extract, Leaf extract, GC-MS, Scavenging activity, Antibacterial, Antifungal

\section{Background}

Plants and their bioactive compounds are a potential source of medicine and are suitable with the prevailing demands for safe and effective treatment. Traditional knowledge procured over years of observation and interaction with the environment is a substantial source of modern medicine. Isolated and purified bioactive

* Correspondence: sivaram.biodiversity@gmail.com

Department of Botany, Bangalore University, Bengaluru, Karnataka 560056, India constituents of the plant can be used for drug development in pharmacology and medicine.

The genus Allium belongs to the family Amaryllidaceae has 500 species and are characterized by their rich content of organo-sulfur as their main bioactive compounds [1]. Allium chinense (Fig. 1) is cultivated in the North-Eastern part of India region; the whole plant is edible raw or cooked and is used in culinary as a flavoring agent. The plant has a strong onion-like aroma and pungent taste, the entire plant is an expectorant,

\section{Springer Open}

(c) The Author(s). 2020 Open Access This article is licensed under a Creative Commons Attribution 4.0 International License, which permits use, sharing, adaptation, distribution and reproduction in any medium or format, as long as you give appropriate credit to the original author(s) and the source, provide a link to the Creative Commons licence, and indicate if changes were made. The images or other third party material in this article are included in the article's Creative Commons licence, unless indicated otherwise in a credit line to the material. If material is not included in the article's Creative Commons licence and your intended use is not permitted by statutory regulation or exceeds the permitted use, you will need to obtain permission directly from the copyright holder. To view a copy of this licence, visit http://creativecommons.org/licenses/by/4.0/. 


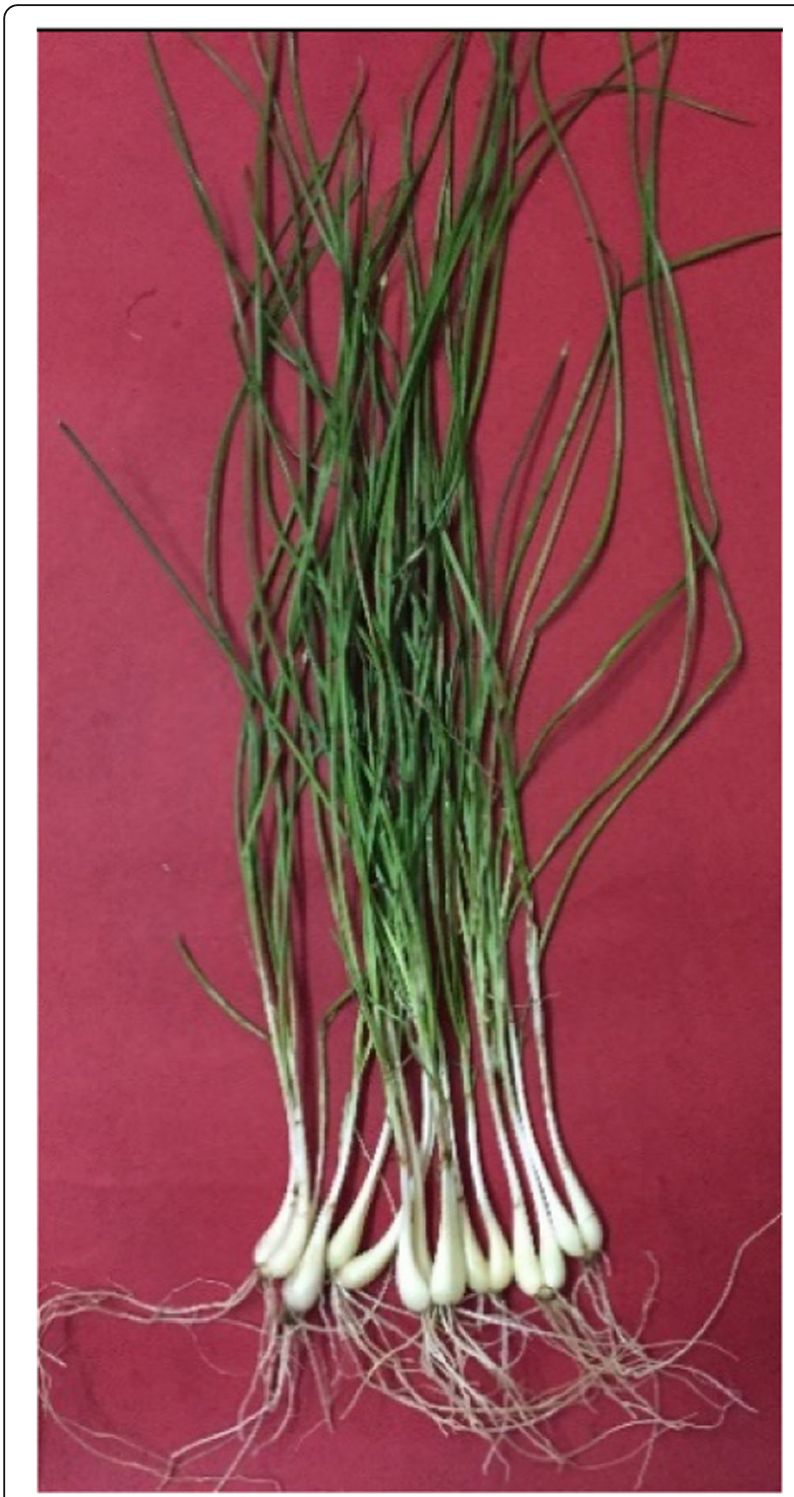

Fig. 1 A. chinense

carminative, and astringent also used to treat bronchitis, diarrhea, and angina pleurisy [2]. The bulb has high medicinal value in traditional Chinese medicine for over thousands of years and is the major source of the "Xiebai" drug used in treating thoracic pain, stenocardia heart, asthma, and stagnant blood [3]. Among the many bioactive compounds present in A. chinense, the important active compounds are steroidal saponins, amino acids, sulfur, nitrogen, and flavonoids compound [4]. The earlier study on $A$. chinense leaf essential oil reported 34 organo-sulfur-containing compounds accounting $94 \%$ of the total volatiles [5]. The chemical investigation carried out in essential oil of the bulb reported a profuse content of sulfide compounds, as high as $97.71 \%$ [6]. Spirostanol saponins extracted from $60 \%$ aqueous methanol extract [7] and laxogenin extracted from hot water extract [8] from A. chinense bulb have anti-tumor property. The protective effects of steroids from $60 \%$ ethanol bulb extract of $A$. chinense have great potential to prevent cardiac injuries induced by oxidative stress [9]. On literature survey, most of the earlier works have been carried out on the bulb and the biological and chemical report on A. chinense leaf is still scarce. However, no report to date has been found on hexane leaf and bulb extract of $A$. chinense. Therefore, the objective of the study was to characterize the chemical profile of the bulb and leaf hexane extract using GC-MS and the second objective was to determine the scavenging activity and antimicrobial activity of $A$. chinense.

\section{Methods}

\section{Collection of plant material}

Fresh and healthy plants of $A$. chinense were collected from the farmers in Kohima district, Nagaland, India. The collected plants were washed, carefully shade-dried till all the moisture contents were removed and ground to a fine powder using an electric grinder and stored in an airtight glass bottle at room temperature $27 \pm 2{ }^{\circ} \mathrm{C}$.

\section{Extraction}

A. chinense leaf and bulb were extracted separately using a soxhlet extractor with $200 \mathrm{ml}$ hexane for $18-20 \mathrm{~h}$. The extracts were separated from the solvent using a rotary evaporator at $30-40{ }^{\circ} \mathrm{C}$ and stored at $4{ }^{\circ} \mathrm{C}$ for further use.

\section{Quantitative analysis \\ Estimation of total alkaloid content}

The total alkaloids were determined using the method described by Tan [10]. Atropine was used as a standard for plotting the calibration curve. The extracts $(1 \mathrm{mg} / \mathrm{ml})$ were dissolved in $2 \mathrm{~N} \mathrm{HCl}$ and washed with chloroform, the layers were separated using a separating funnel, later bromocresol green solution and phosphate buffer $(\mathrm{pH}$ 4.7) were added and the mixture was vortexed, the yellow color complex formed at the bottom was pipetted out to measure the absorbance at $470 \mathrm{~nm}$. The total alkaloid content was estimated using the linear regression equation obtained from the standard graph of atropine further mean $\pm \mathrm{SD}(n=3)$ was calculated and expressed as $\mathrm{mg} / \mathrm{g}$ atropine equivalent $(\mathrm{AE})$.

\section{Estimation of total flavonoids}

Estimation of total flavonoids content was done using the aluminum trichloride $\left(\mathrm{AlCl}_{3}\right)$ method with different concentrations of quercetin as standard [11]. Extracts of $1 \mathrm{mg} / \mathrm{ml}$ were diluted with distilled water and $5 \%$ $\mathrm{NaNO}_{2}$ solution was added. After being incubated for 6 min, $0.15 \mathrm{ml}$ of $\mathrm{AlCl}_{3} 10 \%$ solution was added followed 
by $2 \mathrm{ml}$ of $10 \% \mathrm{NaOH}$, the final volume was adjusted to $5 \mathrm{ml}$ using distilled water, and it was then incubated at room temperature for $15 \mathrm{~min}$. Absorbance was read at $510 \mathrm{~nm}$. All analysis was carried out in triplicate times and the total flavonoid content was calculated using linear regression equation obtained from the standard plot of quercetin and mean $\pm \mathrm{SD}(n=3)$ was calculated. The result was expressed as $\mathrm{mg} / \mathrm{g}$ quercetin equivalent $(\mathrm{QE})$.

\section{Estimation of total phenolic content}

The total phenolics were estimated with FolinCiocalteu's method [12]. Gallic acid at varying concentrations was used as standard; plant extracts $(1 \mathrm{mg} / \mathrm{ml})$, $5 \mathrm{ml}$ of FC (1:10) diluted reagent, and $4 \mathrm{ml}$ sodium bicarbonate $(7.5 \%)$ were taken in a test tube and the mixture was shaken and incubated in the dark for $30 \mathrm{~min}$ at $20^{\circ} \mathrm{C}$. The absorbance was read at $765 \mathrm{~nm}$, all the analysis was performed thrice. The total phenolic content was estimated using the linear regression equation from the standard calibration curve further mean $\pm \mathrm{SD}(n=$ 3) was calculated and expressed as $\mathrm{mg} / \mathrm{g}$ gallic acid equivalent (GAE).

\section{Estimation of saponins}

The saponin content of the extracts was measured as described by Le et al. [13]. Quillaia was used to obtain the standard calibration curve. The sample $(1 \mathrm{mg} / \mathrm{ml})$ was mixed with $500 \mu \mathrm{L}$ of $8 \%$ vanillin and $500 \mu \mathrm{L}$ of $72 \%$ sulfuric acid and incubated at $60^{\circ} \mathrm{C}$ for $10 \mathrm{~min}$ after cooling to room temperature absorbance was recorded at 544 $\mathrm{nm}$. The total saponin content was quantified using the linear regression equation obtained from the standard graph of quillaia further mean $\pm \mathrm{SD}(n=3)$ was quantified as $\mathrm{mg} / \mathrm{g}$ quillaia equivalent (QE). All determination was carried out in triplicates.

\section{2,2-Diphenyl-1-picrylhydrazyl (DPPH) free radical scavenging assay}

The ability of $A$. chinense bulb and leaf extracts to scavenge free radicals was assessed according to the standard DPPH method [14]. Ascorbic acid was used as the standard and the assay was performed in triplicate. One milliliter of the varying concentrations $(1-100 \mu \mathrm{g} / \mathrm{ml})$ was added to $3.0 \mathrm{ml}$ of freshly prepared DPPH (0.06 $\mathrm{mM})$. The mixture was further incubated in the dark for $15 \mathrm{~min}$ at room temperature $\left(27 \pm 2{ }^{\circ} \mathrm{C}\right)$. The decrease in the absorbance was measured at $517 \mathrm{~nm}$ using a UV-Vis spectrophotometer. The percentage of inhibition was calculated using the following formula:

$$
\mathrm{DPPH} \text { radical scavenging activity }(\%)=\left[\left(A_{0}-A_{1}\right) / A_{0}\right] \times 100
$$

where $A_{0}$ is absorbance of control (DPPH) and $A_{1}$ absorbance of extracts
Table 1 Quantitative analysis of A. chinense bulb and leaf extracts

\begin{tabular}{lllll}
\hline $\begin{array}{l}\text { Sl. } \\
\text { No. }\end{array}$ & $\begin{array}{l}\text { Quantitative } \\
\text { analysis }(\mathbf{m g} / \mathbf{g})\end{array}$ & $\begin{array}{l}\text { Linear regression } \\
\text { equation for standard }\end{array}$ & Leaf & Bulb \\
\hline 1 & Alkaloids & $Y=0.0003 X+0.0009, R^{2}$ & $77.000 \pm$ & $77.830 \pm$ \\
& & $=0.9996$ (atropine) & 0.333 & 0.289 \\
2 & Flavonoids & $Y=0.0029 X+0.0031, R^{2}$ & $6.862 \pm$ & $9.275 \pm$ \\
& & $=0.9992$ (quercetin) & 0.597 & 0.398 \\
3 & \multirow{2}{*}{ Phenol } & $Y=0.0127 X+0.0252, R^{2}$ & $18.409 \pm$ & $20.100 \pm$ \\
& & $=0.9991$ (gallic acid) & 0.273 & 0.069 \\
4 & Saponins & $Y=0.0002 x+0.003, R^{2}=$ & 375.000 & 163.750 \\
& & 0.999 (quillaia) & \pm 0.577 & \pm 0.433 \\
\hline
\end{tabular}

Values are mean \pm SE $(n=3)$

The calibration curve for inhibition was prepared and $\mathrm{IC}_{50}$ values were calculated.

\section{Antimicrobial analysis by disk diffusion method}

The antimicrobial activity of the bulb and leaf extract was screened by the agar disk diffusion method. MullerHinton agar (MHA) (Hi-Media) plates were swabbed with gram-positive Staphylococcus aureus (MTCC916) and gram-negative Pseudomonas aeruginosa (MTCC741) bacteria and fungi Aspergillus niger (MTCC281) in Sabouraud dextrose agar (SDA) plate [15]. Plant extracts of $1 \mathrm{mg} / \mathrm{ml}$ concentration were prepared in $0.1 \%$ dimethyl sulfoxide (DMSO). Four wells measuring $6 \mathrm{~mm}$ were bored in the inoculated media with a sterile corkborer. The disks were loaded with $30 \mu \mathrm{l}$ of the extract and placed on the MHA and SDA plate. The Petri-plates were further incubated at $37^{\circ} \mathrm{C}$ for $24 \mathrm{~h}$ for bacteria and $22{ }^{\circ} \mathrm{C}$ for $48 \mathrm{~h}$ for fungi. At the end of incubation, zones of inhibition (ZOI) were observed around the disk and measured with a transparent ruler in millimeters. Streptomycin $(30 \mu \mathrm{g} / \mathrm{ml})$ and fluconazole $(1 \mathrm{mg} / \mathrm{ml})$ were used as the positive control for bacteria and fungi respectively. 0.1\% DMSO was used as a negative control.

\section{GC-MS analysis}

To obtain the complete chemical profile, analysis was performed using GC-MS (SHIMADZU QP2010S) system, with the Rxi-5Sil MS column; length 30 meters, and helium (99.99\%) as a carrier gas at a flow of 1.00

Table 2 Antioxidant activity measured by DPPH scavenging

\begin{tabular}{llll}
\hline Concentration $(\boldsymbol{\mu g} / \mathbf{m l})$ & Ascorbic acid & Leaf extract & Bulb extract \\
\hline 1 & $9.630 \pm 0.057$ & $1.238 \pm 0.133$ & $1.972 \pm 0.010$ \\
10 & $15.313 \pm 0.067$ & $3.665 \pm 0.007$ & $2.369 \pm 0.056$ \\
25 & $29.390 \pm 0.115$ & $5.077 \pm 0.015$ & $4.317 \pm 0.012$ \\
50 & $49.127 \pm 0.037$ & $7.502 \pm 0.018$ & $6.594 \pm 0.032$ \\
75 & $62.160 \pm 0.034$ & $9.036 \pm 0.139$ & $7.479 \pm 0.010$ \\
100 & $83.167 \pm 0.072$ & $10.729 \pm 0.260$ & $8.731 \pm 0.006$ \\
$I_{50}$ & 55.118 & 533.337 & 678.347 \\
\hline
\end{tabular}

Values are mean $\%$ inhibition $\pm \operatorname{SE}(n=3 ; \mathrm{p}<0.05)$ 


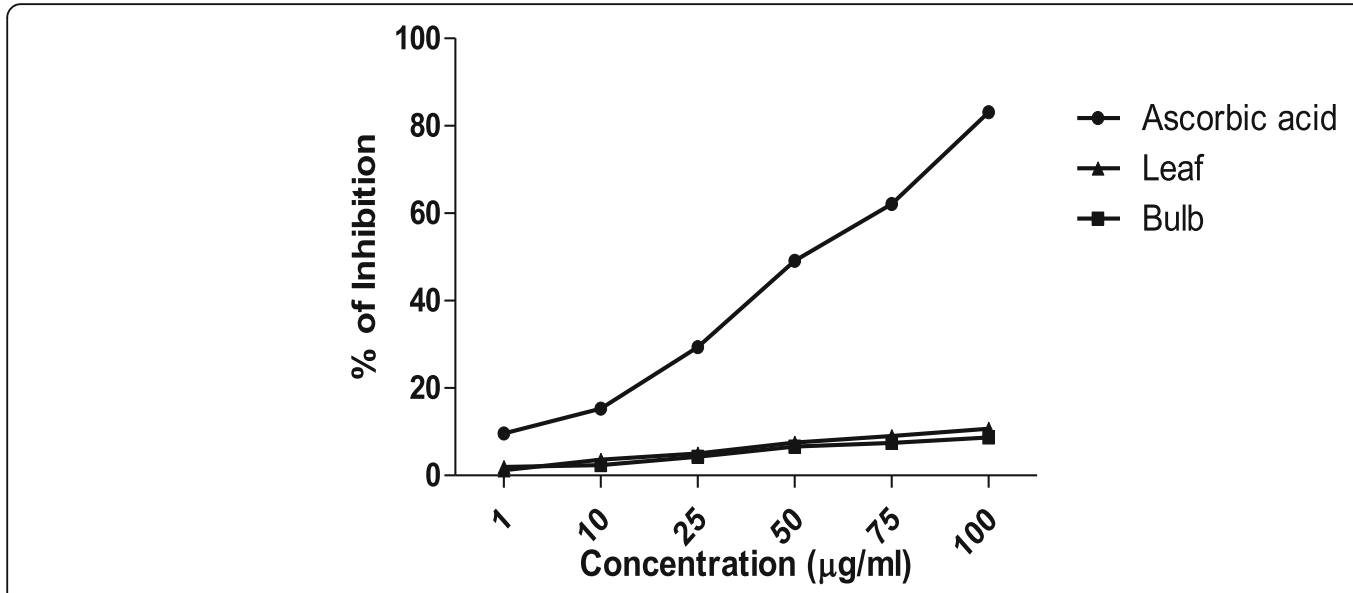

Fig. 2 Scavenging activity of ascorbic acid, bulb, and leaf extract of $A$. chinense

$\mathrm{mL} / \mathrm{min}$. Injection mode was splitless and sampling time $2.00 \mathrm{~min}$; flow control mode was linear velocity at a split ratio 100.0 MS and ID $0.25 \mathrm{~mm}$. The ion source temperature was set at $200.00{ }^{\circ} \mathrm{C}$, interface temperature $280.00^{\circ} \mathrm{C}$, and oven temperature was programmed at $70.0^{\circ} \mathrm{C}$. Solvent cut time was $6.50 \mathrm{~min}$, start time 7.00 $\mathrm{min}$, end time $35.75 \mathrm{~min}$, event time $0.50 \mathrm{~s}$, and scan range $50-500 \mathrm{~m} / \mathrm{z}$.

\section{Identification of compounds}

The identification of chemicals was based on the peaks of the compounds at different mass-to-charge ratios. Results were obtained in accordance with the mass spectral library of National Institute of Standards and Technology, NIST-11. The unknown spectrum was compared with the standard spectrum existing in the database of the WILEY 8 library.

\section{Statistical analysis}

All the estimation was carried out in triplicates. The data obtained in this study were analyzed using a one-way analysis of variance (ANOVA) by using Prism V. 5.00 (Graphpad Inc. USA). The results were expressed as mean \pm SE. Significance value $(P)<0.05$ was selected as a point of minimum significance rate.

\section{Results}

\section{Quantitative analysis}

Phytochemicals have been analyzed quantitatively. The total alkaloid, flavonoid, phenol, and saponin concentration of the bulb and leaf extract are presented in Table 1.

\section{DPPH assay}

The activity of $A$. chinense extract against free radicals is shown in Table 2 and Fig. 2. The A. chinense extract showed less scavenging capacity both in the leaf $\left(\mathrm{IC}_{50}=533.337 \mu \mathrm{g} / \mathrm{ml}\right)$ and bulb $\left(\mathrm{IC}_{50}=\right.$ $678.347 \mu \mathrm{g} / \mathrm{ml}$ ) when compared to standard ascorbic acid $\left(\mathrm{IC}_{50}=55.118 \mu \mathrm{g} / \mathrm{ml}\right)$ with significant difference $(p<0.05)$.

\section{Antimicrobial activity}

Antimicrobial activity was observed in all the species tested (Table 3, Fig. 3). The extracts of $A$. chinense exhibited exquisite antibacterial activity with $15 \mathrm{~nm}$ (leaf) and10 $\mathrm{nm}$ (bulb) ZOI in gram-positive (Staphylococcus aureus) and $20 \mathrm{~mm}$ (leaf) and $16 \mathrm{~mm}$ (bulb) ZOI in gram-negative bacteria (Pseudomonas aeruginosa). The absence of ZOI was interpreted as the absence of activity. In Aspergillus niger, bulb extract showed $7 \mathrm{~mm}$ ZOI and $14 \mathrm{~mm} \mathrm{ZOI} \mathrm{in} \mathrm{the} \mathrm{leaf}$ extract.

Table 3 Diameter of zones of inhibition $(\mathrm{mm}$ ) of bulb and leaf extract of $A$. chinense against tested microorganisms

\begin{tabular}{llll}
\hline Sample/test organism & Staphylococcus aureus (gram-positive) (mm) & $\begin{array}{l}\text { Pseudomonas aeruginosa } \\
\text { (gram-negative) (mm) }\end{array}$ & $\begin{array}{l}\text { Aspergillus niger } \\
(\mathbf{m m})\end{array}$ \\
\hline Leaf & 15 & 20 & 14 \\
Bulb & 10 & 16 & 7 \\
Positive control & 16 & 18 & 16 \\
Negative control & $\mathrm{NA}$ & $\mathrm{NA}$ & $\mathrm{NA}$
\end{tabular}




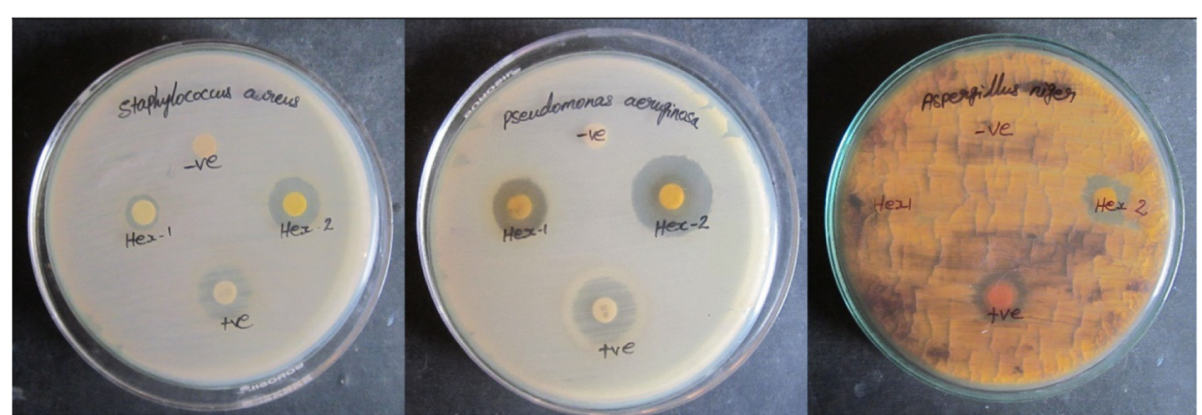

Fig. 3 Growth inhibition of S. aureus, P. aeruginosa, and A. niger caused by A. chinense bulb (Hex-1) and leaf (Hex-2) extracts

\section{GC-MS analysis}

GC-MS analysis is a superior technique to identify the phytoconstituents. Nine compounds were identified from hexane leaf extract and twenty-eight compounds from hexane bulb representing $100 \%$ of the total extract. The identification was based on retention time, peak area, molecular formula, molecular weight, and molecular structure which are shown in (Figs. 4 and 5, Tables 4 and 5). The GC-MS analysis of hexane leaf extract revealed the presence of this compounds viz., perhydrofarnesyl acetone, phytol, nonadecane, 2-methyl-, heptadecyl heptaflurobutyrate, eicosane, 7-hexyl-, octadecyl trifluoroacetate, gamma-tocopherol, tetratetracontane, heptadecane, 2,6dimethyl- and the compounds identified in the bulb are 9 , 12 octadecadienoic acid, methyl ester, tritetracontane, 1ethylsulfanylmethyl-2,8,9-trioxa-5-aza-1-sila-bicyclo[3.3.3] undecane, 3,6,9,12-tetraoxahexadecan-1-ol, 9,12-octadecadienoic acid, ethyl ester, 3,4,4a,5,6,7,8,8a-octahydro-spiro[cyclohexane-1,4'-(2H-1,3-benzothiazine)]-2-thione-8a-ol, heptadecane, 4,8,12,16-tetramethylheptadecan-4-olide, hexadecanoic acid, 2-methylpropyl ester, nonadecane, 2methyl-, hexadecanoic acid,3-[(trimethylsilyl)oxy] propyl ester, hexadecanoic acid-2-hydroxyl-1- (hydroxy methyl) ethyl ester, eicosane, 10-methyl-, diisooctyl phthalate, npropyl 9,12-octadecadienoate, eicosane, 2-methyl-, cyclopropane, 1,1-dichloro-2,2,3,3-tetramethyl-, 1- heneicosanol, 1-heptacosanol, 2-methyloctacosane, octadecyl trifluoroacetate, eicosane, 7-hexyl, n-tetracosanol-1, tetratetracontane, docosane, 11-butyl-, heneicosane, nnonadecanol-1, and vitamin E.

\section{Discussion}

In the quantitative estimation of $A$. chinense bulb and leaf, high content of saponin was observed. Saponin possesses antibiotic, insecticidal, and fungicidal activity [16]. Steroidal saponins isolated from $A$. chinense bulb possess anti-tumor property [7]. Saponins are cytotoxic and inhibit the migration ability of B16 and 4T1 cells [4]. Laxogenin a saponin isolated from $A$. chinense bulb have anti-tumor property in stage-two lung carcinogenesis [8]. Therefore, $A$. chinense can be used as a potential plant for the extraction of saponin for medicinal and pharmaceutical use.

Alkaloids have been reported to have anticancer, antibacterial, antiviral, and antifungal activity [17]. Aclidinium bromide a drug from alkaloid is used to treat chronic obstructive pulmonary disease; atropine and scopolamine are alkaloid derivatives used in traditional medicine for treating asthma [18]. A. chinense showed a moderate content of alkaloids which

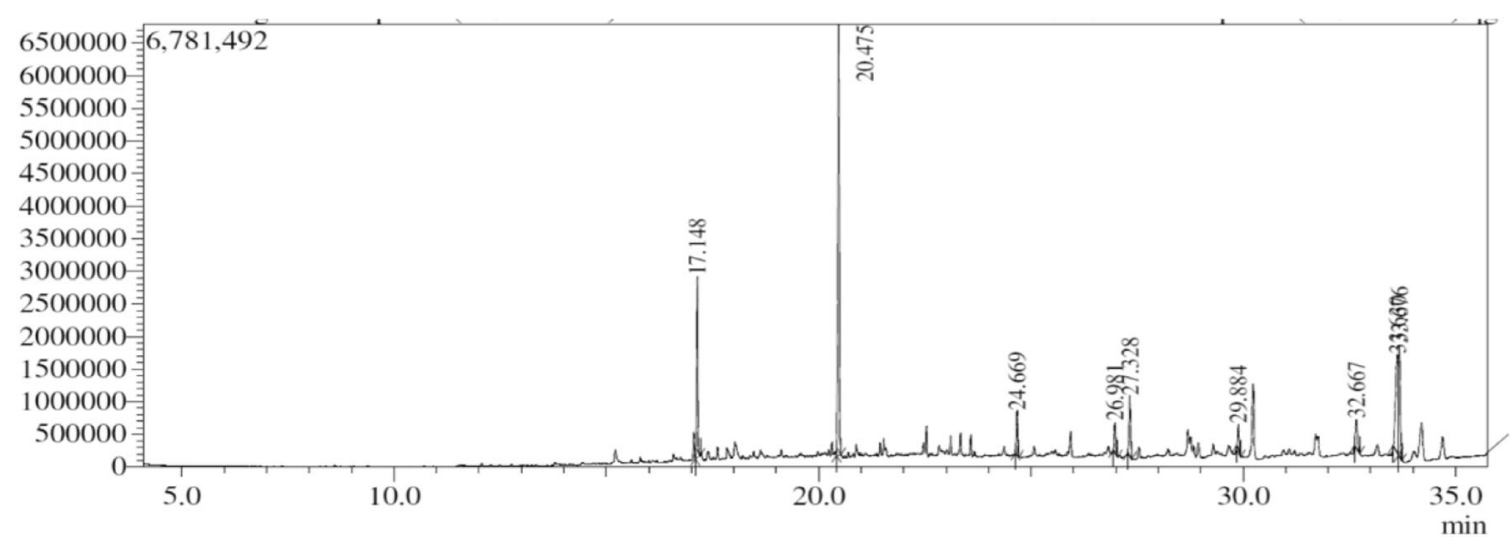

Fig. 4 GC-MS chromatogram of hexane extract of A. chinense leaf 


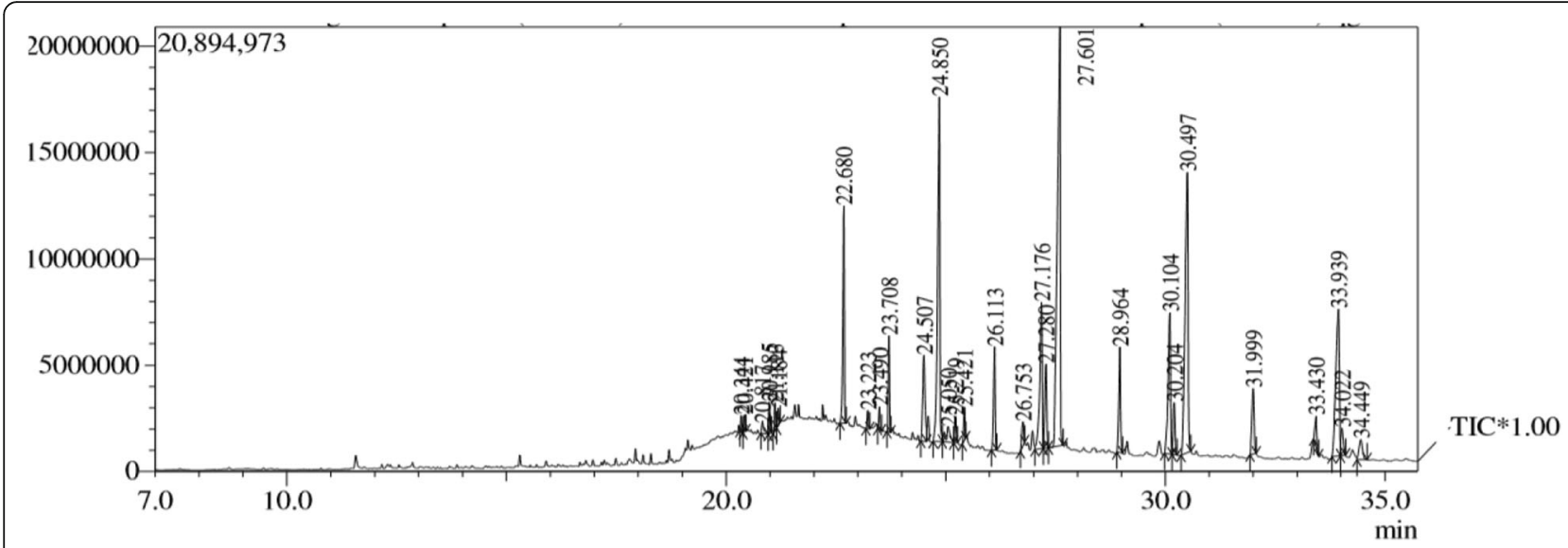

Fig. 5 GC-MS chromatogram of hexane extract of A. chinense bulb

could be exploited for their pharmacological properties.

Low content of phenols [19] and flavonoids [20] indicate low antioxidant activity. Phenols are known to have anti-inflammatory, antimicrobial, anesthetic, antioxidant, anti-tubercular, anticancer, analgesic, and anti-Parkinson activity [21]. Flavonoids are known to have antioxidant effects and have been shown to inhibit the initiation and progression promotion of tumors [22]; consumption of flavonoids decreases coronary heart disease [23].

$\mathrm{DPPH}$ is a stable free radical with absorption spectra at $517 \mathrm{~nm}$ and loses its ideal absorption accepting an electron, resulting in a change from purple to yellow color, displaying the scavenging potential [24]. The low or negligible antioxidant capacity in the hexane leaf and bulb extract may be due to the low content of phenol [19] and flavonoid [20]. Our findings correlate with the previous report by $\mathrm{Lin}$ in $\mathrm{A}$. chinense bulb [25].

The leaf extract showed higher antibacterial activity $(20 \mathrm{~mm})$ than the standard $(18 \mathrm{~mm})$ against $P$. aeruginosa, it is known that gram-negative bacteria are highly resistant to many antibiotics. The absence of ZOI was interpreted as the absence of activity. The activities are expressed as resistant if ZOI was less than $7 \mathrm{~mm}$, intermediate $(8-10 \mathrm{~mm})$, and sensitive if more than $11 \mathrm{~mm}$ [26]. On observing the zone of inhibition, the bulb exhibited resistant activity whereas leaf was highly sensitive as an antibacterial. In A. niger, bulb extract showed intermediate $(7 \mathrm{~mm})$ activity whereas sensitive activity with $14 \mathrm{~mm}$ ZOI was observed in the leaf extract. The high composition of terpene, viz. phytol $(35.76 \%)$ and perhydrofarnesyl (14.7\%) in the leaf and 2-methyl octacosane $(21.30 \%)$ in the bulb exhibited antimicrobial activity
[19, 24, 27]. The leaf extract has an outstanding antibacterial activity against gram-negative bacteria $P$. aeruginosa.

The result of the current study supports the use of both bulb and leaf hexane extracts as a potential antibacterial and antifungal; the leaf extract presented as a wide antimicrobial spectrum compared to the bulb.

The GC-MS characterization revealed that the compounds found in both the bulb and leaves extract were not reported earlier in this plant. The difference in results reported in essential oil [6] may be due to the extraction method, soil $\mathrm{pH}$, seasonal variation, climatic conditions, and many other factors.

In the leaf extract, phytol was the major component identified with a concentration of $35.76 \%$ and retention time of 20.475 min which is an acyclic diterpene with anticancer, anti-diuretic, nematicide, hepatoprotective, hypocholesterolemic, anticoronary, antiandrogenic antimicrobial, antioxidant, antiarthritic, anti-inflammatory, antidiabetic, and immunostimulatory [27] followed by tetratetracontane with a peak area of $18.49 \%$ appeared at $33.630 \mathrm{~min}$ is a long chain alkane, having antibacterial activity [28]. Perhydrofarnesyl acetone with $14.76 \%$ was the first compound detected in the leaf at $17.148 \mathrm{~min}$ and is a sesquiterpenoid that has extensive biological activities such as, antimicrobial, allelopathic, cytotoxic, and antifeedant activity [29].

The GC-MS analysis of the bulb displayed alkane as the major group. In the 28 compounds revealed, the dominance of compounds such as 2-methyloctacosane with the peak area of $21.30 \%$ appeared at $27.601 \mathrm{~min}$ which is an alkane with antimicrobial [30]. Tetratetracontane with a peak area of $14.05 \%$ which appeared at $30.497 \mathrm{~min}$ is an alkane having antibacterial 
Table 4 Phytocompounds identified in the hexane extract of A. chinense leaf by GC-MS analysis

\begin{tabular}{|c|c|c|c|c|c|}
\hline $\begin{array}{c}\text { Retent } \\
\text { ion } \\
\text { time }\end{array}$ & $\begin{array}{l}\text { Name of the } \\
\text { compound }\end{array}$ & $\begin{array}{c}\text { Peak } \\
\text { Area } \\
\%\end{array}$ & $\begin{array}{l}\text { Mol. } \\
\text { Wt. }\end{array}$ & Structure & $\begin{array}{l}\text { Nature of } \\
\text { compounds }\end{array}$ \\
\hline $\begin{array}{c}17.14 \\
8\end{array}$ & $\begin{array}{c}\text { Perhydrofarnesyl } \\
\text { acetone } \\
\mathrm{C}_{18} \mathrm{H}_{36} \mathrm{O}\end{array}$ & $\begin{array}{c}14.7 \\
6\end{array}$ & 268 & & Sesquiterpenoids \\
\hline $\begin{array}{c}20.47 \\
5\end{array}$ & $\begin{array}{c}\text { Phytol } \\
\mathrm{C}_{22} \mathrm{H}_{42} \mathrm{O}_{2}\end{array}$ & $\begin{array}{c}35.7 \\
6\end{array}$ & 338 & & Diterpene \\
\hline $\begin{array}{c}24.66 \\
9\end{array}$ & $\begin{array}{c}\text { Nonadecane, 2- } \\
\text { methyl- } \\
\mathrm{C}_{20} \mathrm{H}_{42}\end{array}$ & 3.61 & 282 & $M W M M$ & Alkane \\
\hline $\begin{array}{c}26.98 \\
1\end{array}$ & $\begin{array}{c}\text { Heptadecyl } \\
\text { heptaflurobutyrate } \\
\mathrm{C}_{21} \mathrm{H}_{35} \mathrm{~F}_{7} \mathrm{O}_{2}\end{array}$ & 3.03 & 452 & & Alkyl \\
\hline $\begin{array}{c}27.32 \\
8\end{array}$ & $\begin{array}{l}\text { Eicosane, 7-hexyl- } \\
\mathrm{C}_{26} \mathrm{H}_{54}\end{array}$ & 6.56 & 366 & & Alkane \\
\hline $\begin{array}{c}29.88 \\
4\end{array}$ & $\begin{array}{c}\text { Octadecyl } \\
\text { trifluroacetate } \\
\mathrm{C}_{20} \mathrm{H}_{37} \mathrm{~F}_{3} \mathrm{O}_{2}\end{array}$ & 2.73 & 366 & & Esters \\
\hline $\begin{array}{c}32.66 \\
7\end{array}$ & $\begin{array}{c}\text { gamma.-Tocopherol } \\
\mathrm{C}_{28} \mathrm{H}_{48} \mathrm{O}_{2}\end{array}$ & 4.27 & 416 & & Vitamin E \\
\hline $\begin{array}{c}33.63 \\
0\end{array}$ & $\begin{array}{l}\text { Tetratetracontane } \\
\mathrm{C}_{44} \mathrm{H}_{90}\end{array}$ & $\begin{array}{c}18.4 \\
9\end{array}$ & 619 & & Alkane \\
\hline $\begin{array}{c}33.67 \\
6\end{array}$ & $\begin{array}{l}\text { Heptadecane, 2,6- } \\
\text { dimethyl- } \\
\mathrm{C}_{19} \mathrm{H}_{40}\end{array}$ & $\begin{array}{c}10.7 \\
9\end{array}$ & 268 & & Alkane \\
\hline
\end{tabular}

property [28]. Eicosane, 10-methyl with a peak area of $12.06 \%$ appeared at $24.850 \mathrm{~min}$, an alkane which has high antioxidant [31]. Heneicosane with a peak area of $8.46 \%$ reported at $33.939 \mathrm{~min}$ is an aliphatic hydrocarbon; it belongs to the higher alkane group having bio pesticidal property [32].

The GC-MS revealed that the bulb and leaves have a different bio-constituent; only three compounds tetratetracontane, nonadecane, and 2-methyl-octadecyl trifluoroacetate appeared in both the extract. Our findings on the chemical composition of hexane bulb and leaf extract did not correlate with the previous reports on the essential oil $[5,6]$ and no sulfide- containing compounds were identified in the crude extract.

\section{Conclusion}

The quantitative analysis showed a high content of saponins in the leaf extract. GC-MS analysis of the extract suggests that numerous medicinally important bioactive constituents are present in $A$. chinense leaf and bulb, with high terpene content in the leaf and alkanes in the bulb.

These important findings revealed through our study suggest isolation of bioactive compounds, and screening its activity will have tremendous 
Table 5 Phytocompounds identified in the hexane extract of $A$. chinense bulb by GC-MS analysis

\begin{tabular}{|c|c|c|c|c|c|}
\hline \begin{tabular}{|l|} 
Retent \\
ion \\
Time \\
\end{tabular} & $\begin{array}{c}\text { Peak } \\
\text { Area } \\
\%\end{array}$ & Name of the compound & $\begin{array}{c}\text { Mol. } \\
\text { weig } \\
\text { ht }\end{array}$ & Mol. structure & Nature of compound \\
\hline $\begin{array}{c}20.34 \\
4\end{array}$ & 0.29 & $\begin{array}{c}9,12 \text { Octadecadienoic } \\
\text { acid, methyl ester } \\
\mathrm{C}_{19} \mathrm{H}_{34} \mathrm{O}_{2}\end{array}$ & 294 & & Linoleic acid ester \\
\hline $\begin{array}{c}20.42 \\
1\end{array}$ & 0.34 & $\begin{array}{c}\text { Tritetracontane } \\
\mathrm{C}_{43} \mathrm{H}_{88} \\
\end{array}$ & 605 & nun & Alkane \\
\hline $\begin{array}{c}20.81 \\
7\end{array}$ & 0.41 & $\begin{array}{c}\text { 1-Ethylsulfanylmethyl- } \\
\text { 2,8,9-trioxa-5-aza-1- } \\
\text { sila-bicyclo[3.3.3] } \\
\text { undecane } \\
\mathrm{C}_{9} \mathrm{H}_{19} \mathrm{NO}_{3} \mathrm{SSi} \\
\end{array}$ & 249 & & Aromatic compound \\
\hline $\begin{array}{c}20.98 \\
5\end{array}$ & 0.66 & $\begin{array}{c}3,6,9,12- \\
\text { Tetraoxahexadecan-1-ol } \\
\mathrm{C}_{12} \mathrm{H}_{26} \mathrm{O}_{5}\end{array}$ & 250 & & Terpene alcohol \\
\hline $\begin{array}{c}21.11 \\
3\end{array}$ & 0.56 & $\begin{array}{c}\text { 9,12-Octadecadienoic } \\
\text { acid, ethyl ester } \\
\mathrm{C}_{20} \mathrm{H}_{36} \mathrm{O}_{2}\end{array}$ & 308 & & Polyenoic fatty acid \\
\hline $\begin{array}{c}21.18 \\
4\end{array}$ & 0.36 & $\begin{array}{c}\text { 3,4,4a,5,6,7,8,8a- } \\
\text { Octahydro- } \\
\text { spiro[cyclohexane-1,4'- } \\
(2 \mathrm{H}-1,3- \\
\text { benzothiazine)]-2- } \\
\text { thione-8a-ol } \\
\mathrm{C}_{13} \mathrm{H}_{21} \mathrm{NOS}_{2} \\
\end{array}$ & 271 & & Aromatic compound \\
\hline $\begin{array}{c}22.68 \\
0\end{array}$ & 4.97 & $\begin{array}{c}\text { Heptadecane } \\
\mathrm{C}_{17} \mathrm{H}_{36}\end{array}$ & 240 & $M$ & Alkane \\
\hline $\begin{array}{c}23.22 \\
3\end{array}$ & 0.38 & $\begin{array}{c}4,8,12,16- \\
\text { Tetramethylheptadecan- } \\
\text { 4-olide } \\
\mathrm{C}_{21} \mathrm{H}_{40} \mathrm{O}_{2} \\
\end{array}$ & 324 & & Terpenoids \\
\hline $\begin{array}{c}23.49 \\
0\end{array}$ & 0.45 & $\begin{array}{l}\text { Hexadecanoic acid, 2- } \\
\text { methylpropyl ester } \\
\mathrm{C}_{20} \mathrm{H}_{40} \mathrm{O}_{2}\end{array}$ & 312 & & Fatty acid \\
\hline $\begin{array}{c}23.70 \\
8\end{array}$ & 1.86 & $\begin{array}{l}\text { Nonadecane, 2-methyl- } \\
\mathrm{C}_{20} \mathrm{H}_{42}\end{array}$ & 282 & $w$ & $\begin{array}{c}\text { Volatile heterocyclic } \\
\text { hydrocarbon }\end{array}$ \\
\hline $\begin{array}{c}24.50 \\
7\end{array}$ & 3.46 & $\begin{array}{c}\text { Hexadecanoic acid,3- } \\
\text { [(trimethylsilyl)oxy] } \\
\text { propyl ester } \\
\mathrm{C}_{22} \mathrm{H}_{46} \mathrm{O}_{3} \mathrm{Si} \\
\end{array}$ & 386 & & Fatty acid ester \\
\hline $\begin{array}{c}24.85 \\
0\end{array}$ & $\begin{array}{c}12.0 \\
6\end{array}$ & $\begin{array}{c}\text { Eicosane, 10-methyl- } \\
\mathrm{C}_{21} \mathrm{H}_{44}\end{array}$ & 296 & $m m m m m$ & Alkane \\
\hline $\begin{array}{c}25.05 \\
0\end{array}$ & 1.08 & $\begin{array}{c}\text { Hexadecanoic acid-2- } \\
\text { hydroxyl-1- (hydroxy } \\
\text { methyl) ethyl ester } \\
\mathrm{C}_{19} \mathrm{H}_{38} \mathrm{O}_{4} \\
\end{array}$ & 330 & & Amino compound \\
\hline $\begin{array}{c}25.21 \\
9\end{array}$ & 0.63 & $\begin{array}{c}\text { Diisooctyl phthalate } \\
\mathrm{C}_{8} \mathrm{H}_{4} \\
\left(\mathrm{C}_{8} \mathrm{H}_{17} \mathrm{COO}\right)_{2}\end{array}$ & 390 & & $\begin{array}{l}\text { Plasticizer } \\
\text { compound }\end{array}$ \\
\hline $\begin{array}{c}25.42 \\
1\end{array}$ & 0.81 & $\begin{array}{c}\text { n-propyl 9,12- } \\
\text { octadecadienoate } \\
\mathrm{C}_{21} \mathrm{H}_{38} \mathrm{O}_{2}\end{array}$ & 322 & & Fatty acid ester \\
\hline $\begin{array}{c}26.11 \\
2\end{array}$ & 2.95 & $\begin{array}{c}\text { Eicosane, 2-methyl- } \\
\mathrm{C}_{21} \mathrm{H}_{44} \\
\end{array}$ & 296 & $m$ & Alkane \\
\hline $\begin{array}{c}26.75 \\
3\end{array}$ & 0.80 & $\begin{array}{c}\text { Cyclopropane, 1,1- } \\
\text { dichloro-2,2,3,3- } \\
\text { tetramethyl- } \\
\mathrm{C}_{7} \mathrm{H}_{12} \mathrm{Cl}_{2} \\
\end{array}$ & 167 & & Carboxylic acid \\
\hline $\begin{array}{c}27.17 \\
6\end{array}$ & 5.76 & $\begin{array}{c}\text { 1- Heneicosanol } \\
\mathrm{C}_{21} \mathrm{H}_{44} \mathrm{O}\end{array}$ & 312 & moms & Primary fatty alcohol \\
\hline $\begin{array}{c}27.28 \\
0\end{array}$ & 2.58 & $\begin{array}{c}\text { 1-Heptacosanol } \\
\mathrm{C}_{27} \mathrm{H}_{56} \mathrm{O}\end{array}$ & 396 & WMWmWm & \begin{tabular}{|l|} 
Primary fatty alcohol \\
\end{tabular} \\
\hline $\begin{array}{c}27.60 \\
1\end{array}$ & $\begin{array}{c}21.3 \\
0\end{array}$ & $\begin{array}{l}\text { 2-methyloctacosane } \\
\qquad \mathrm{C}_{29} \mathrm{H}_{60}\end{array}$ & 408 & mon & Alkane \\
\hline $\begin{array}{c}28.96 \\
4\end{array}$ & 3.22 & $\begin{array}{c}\text { Eicosane, 7-hexyl } \\
\mathrm{C}_{26} \mathrm{H}_{54}\end{array}$ & 366 & & $\begin{array}{l}\text { Aliphatic hydro } \\
\text { compounds }\end{array}$ \\
\hline $\begin{array}{c}30.10 \\
4\end{array}$ & 5.57 & $\begin{array}{c}\text { Octadecyl } \\
\text { trifluoroacetate } \\
\mathrm{C}_{20} \mathrm{H}_{37} \mathrm{~F}_{3} \mathrm{O}_{2} \\
\end{array}$ & 366 & & Esters \\
\hline $\begin{array}{c}30.20 \\
4\end{array}$ & 1.65 & $\begin{array}{c}\text { n-tetracosanol-1 } \\
\mathrm{C}_{24} \mathrm{H}_{50} \mathrm{O}\end{array}$ & 354 & MWWWWM & Primary fatty alcohol \\
\hline $\begin{array}{c}30.49 \\
7 \\
\end{array}$ & $\begin{array}{c}14.0 \\
5\end{array}$ & $\begin{array}{c}\text { Tetratetracontane } \\
\mathrm{C}_{44} \mathrm{H}_{90} \\
\end{array}$ & 619 & nunnumunn: & Alkane \\
\hline $\begin{array}{c}31.99 \\
9\end{array}$ & 2.40 & $\begin{array}{c}\text { Docosane, 11-butyl- } \\
\mathrm{C}_{26} \mathrm{H}_{54} \\
\end{array}$ & 366 & & Alkane \\
\hline $\begin{array}{c}33.43 \\
0\end{array}$ & 0.91 & $\begin{array}{c}\text { Octadecyl } \\
\text { trifluroacetate } \\
\mathrm{C}_{20} \mathrm{H}_{37} \mathrm{~F}_{3} \mathrm{O}_{2} \\
\end{array}$ & 366 & & Esters \\
\hline $\begin{array}{c}33.93 \\
9\end{array}$ & 8.46 & $\begin{array}{c}\text { Heneicosane } \\
\mathrm{C}_{21} \mathrm{H}_{44}\end{array}$ & 296 & MWMm & $\begin{array}{c}\text { Aliphatic } \\
\text { hydrocarbon }\end{array}$ \\
\hline $\begin{array}{c}34.02 \\
2\end{array}$ & 0.93 & $\begin{array}{c}\text { n-Nonadecanol-1 } \\
\mathrm{C}_{19} \mathrm{H}_{40} \mathrm{O}\end{array}$ & 284 & $M M m w^{1}$ & Alcoholic compound \\
\hline $\begin{array}{c}34.44 \\
9\end{array}$ & 1.10 & $\begin{array}{l}\text { Vitamin E } \\
\mathrm{C}_{29} \mathrm{H}_{50} \mathrm{O}_{2}\end{array}$ & 430 & & Vitamin \\
\hline
\end{tabular}

benefits, considering its availability, that it is edible and has medicinal value, and that it is non-toxic; however, a toxicological analysis would be of necessity to develop safe drugs. This work represents an initial step to understand the plant phytochemical constitution which could facilitate further investigation.

\section{Abbreviations}

$\mathrm{AlCl}_{3}$ : Aluminum trichloride; AE: Atropine equivalent; DMSO: Dimethyl sulfoxide; DPPH: 2,2-Diphenyl-1-picrylhydrazyl; FC: Folin-ciocalteu; GAE: Gallic acid equivalent; GC-MS: Gas chromatography-mass spectroscopy; $\mathrm{HCl}$ : Hydrochloric acid; MHA: Mueller-Hinton agar; NA: No activity; $\mathrm{NaOH}$ : Sodium hydroxide; $\mathrm{NaNO}_{2}$ : Sodium Nitrite; NIST: National Institute of Standards and Technology; QE: Quercetin equivalent; QE: Quillaia equivalent; SDA: Sabouraud dextrose agar; SE: Standard error; UV-Vis: Ultraviolet-visible; ZOI: Zone of inhibition

\section{Acknowledgements}

The authors are thankful to the Department of Botany, Bangalore University, Bangalore 560056, for providing facilities, and Central Instrumentation Unit, Kerala Forest Research Institute (KFRI), Peechi, Thrissur, Kerala, India, for GCMS analysis.

\section{Plant authentication}

The plant was authenticated by Dr. V Rama Rao, Regional Ayurveda Research Institute for Metabolic Disorders, Central Council for Research in Ayurvedic Sciences, Ministry of AYUSH, Govt. of India, Bengaluru 560109. The authenticated sample was preserved with the specimen voucher number RRCBI-mus 244.

\section{Authors' contributions}

TR performed all the above analysis and drafted the manuscript. SR participated in performing the analysis and interpretation of the data. RMS participated in performing the analysis. VS participated in the design, drafting, and critically revising the manuscript. All authors have read and approved the manuscript

\section{Funding}

The first author is thankful to the University Grant Commission (UGC) Maulana Azad National Fellowship (MANF) of the Government of India for providing Senior Research Fellowship (SRF).

\section{Availability of data and materials}

The data used to analyze the findings of this study are available from the corresponding author upon request.

\section{Ethics approval and consent to participate}

Not applicable.

\section{Consent for publication}

Not applicable.

\section{Competing interests}

The authors declare that they have no competing interests.

Received: 9 March 2020 Accepted: 31 August 2020

Published online: 27 November 2020

\section{References}

1. Yang MH, Kim N, Heo J, Rho J, Ock KJ, Shin E, Jeong EJ (2017) Comparative evaluation of sulfur compounds contents and antiobesity properties of Allium hookeri prepared by different drying methods. Evidence-Based Complementary and Alternative Medicine https://doi.org/10.1155/2017/ 2436927

2. Yeung HC (1995) Handbook of chinese herbs and formulas. Institute of Chinese Medicine, Los Angeles

3. Shanghai Institute of Science and Technological Information (1977) Shanghai compilation of new drugs confirmed in 1976 Shanghai. 
4. Yu Z, Zhang T, Zhou F, Xiao X, Ding X, He H, Rang J, Quan M, Wang T, Zuo $M$, Xia $L$ (2015) Anticancer activity of saponins from Allium chinense against the B16 melanoma and 4T1 breast carcinoma cell. Evidence-Based Complementary and Alternative Medicine. https://doi.org/10.1155/2015/ 725023

5. Pino JA, Fuentes V, Correa MT (2001) Volatile constituents of Chinese chive (Allium tuberosum Rottl. Ex Sprengel) and Rakkyo (Allium chinense G. Don). Journal of Agricultural and Food Chemistry 49: $1328-1330$

6. Liu XC, Lu XN, Liu QZ, Liu ZL (2014) Evaluation of insecticidal activity of the essential oil of Allium chinense G. Don and its major constituents against Liposcelis bostrychophila Badonnel. Journal of Asia-Pacific Entomology 17(4):853-856

7. Wang Y, Li C, Xiang L, Huang W, He X (2016) Spirostanol saponins from Chinese onion (Allium chinense) exert pronounced anti-inflammatory and anti-proliferative activities. Journal of Functional Foods 25:208-219. https:// doi.org/10.1016/j.jff.2016.06.005

8. Baba M, Ohmura M, Kishi N, Okada Y, Shibata S, Peng J, Yao S, Nishino H, Okuyama T (2000) Saponins isolated from Allium chinense G. DON and antitumor-promoting activities of isoliquiritigenin and laxogenin from the same drug. Biological and Pharmaceutical Bulletin 23:660-662. https://doi. org/10.1248/bpb.23.660

9. Ren G, Qiao HX, Yang J, Zhou CX (2009) Protective effects of steroids from Allium chinense against H2O2-induced oxidative stress in Rat cardiac H9C2 cells. Phytotherapy Research 24:404-409

10. Tan PV (2018) The determination of total alkaloid, polyphenol, flavonoid and saponin contents of Pogang gan (Curcuma sp.). International Journal of Biology 10(4):42-47

11. Deshmukh MA, Theng MA (2017) Phytochemical screening, quantitative analysis of primary and secondary metabolites of Acacia arabica bark. International Journal of Current Pharmaceutical Research 10(2):35-37

12. Khan AN, Bhat I (2018) Extraction, qualitative and quantitative determination of secondary metabolites of Rumex nepalensis roots. Journal of Drug Delivery and Therapeutics 8(6):97-100

13. Le AV, Parks SE, Nquyen MH, Roach PD (2018) Improving the vanillinsulphuric acid method for quantifying total saponins. Technologies 6(3):84

14. Vasundhara M, Nethravathi M, Priyanka R, Marappa N, Gujaran SR (2017) Antioxidant potential of Laurus nobilis L. essential oil. Agricultural Research Journal 54(4):495-499

15. Yamac M, Bilgili F (2006) Antimicrobial activities of fruit bodies and/or mycelial cultures of some mushroom isolates. Pharmaceutical Biology 44(9): 660-667

16. Desai SD, Desai DG, Kaur H (2009) Saponins and their biological activities. PharmaTimes 41(3):13-16

17. Thawabteh A, Juma S, Bader M, Karaman D, Scrano L, Bufo SA, Karaman R (2019) The biological activity of natural alkaloids against herbivores, cancerous cells and pathogens. Toxins. https://doi.org/10.3390/ toxins 11110656

18. Kittakoop P, Mahidol C, Ruchirawat S (2014) Alkaloids as important scaffolds in therapeutic drugs for the treatments of cancer, tuberculosis, and smoking cessation. Current Topics in Medicinal Chemistry 14:239-252

19. Hazzit M, Baaliouamer A, Verissimo AR, Falei-ro ML, Miguel MG (2009) Chemical composition and biological activities of Algerian Thymus oils. Food Chemistry 116:714-721

20. Kathirvel A, Sujatha V (2016) Phytochemical studies, antioxidant activities and identification of active compounds using GC-MS of Dryopteris cochleate leaves. Arabian Journal of Chemistry 9:1435-1442

21. Kumar A, Mishra AK (2018) Biological importance of phenol derivatives as potent bioactive compound: a review. Letters in Organic Chemistry 15(4): $251-264$

22. Kim SY, Kim JH, Kim SK, Oh MJ, Jung MY (1994) Antioxidant activities of selected oriental herb extracts. Journal of the American Oil Chemists' Society 71(6):633-640

23. Hertog MGL, Feskens EJM, Hollman PCH, Katan MB, Kromhout D (1993) Dietary antioxidant flavonoids and risk of coronary heart disease: the Zutphen Elderly Study. The Lancet 342(8878):1007-1101

24. Sowndhararajan K, Joseph JM, Rajendrakumaran D, Manian S (2010) In vitro antioxidant characteristics of different parts of Melothria maderaspatana (L.) Cogn. International Journal of Pharmacy and Pharmaceutical Sciences 2(3): $117-123$
25. Lin YP, Lin LY, Yeh HY, Chuang CH, Tseng SW, Yen YH (2016) Antihyperlipidemic activity of Allium chinense bulbs. Journal of Food and Drug Analysis 24(3):516-526

26. Assam AJP, Dzoyem JP, Pieme CA, Penlap VB (2010) In vitro antibacterial activity and acute toxicity studies of aqueous-methanol extract of Sida rhombifolia Linn. (Malvaceae). BMC Complement Altern Med. https://doi. org/10.1186/1472-6882-10-40

27. Rajesh KD, Dabur R, Vasantha S, Panneerselvan A, Rajesh NV, Jeyathilakan N (2016) Phytochemical analysis, in vitro antioxidant potential and gas chromatography-mass spectrometry studies of Dicranopteris linearis. Asian Journal of Pharmaceutical and Clinical Research 9(8):220-225

28. Gumgumjee NM, Hajar AS (2015) Antibacterial activities and GC-MS analysis of phytocomponents of Ehretia abyssinica R. Br. ex Fresen. International Journal of Applied Biology and Pharmaceutical technology 6(2):236-241

29. Durán-Peña MJ, Botubol Ares JM, Hanson JR, Collado IG, Hernández-Galán R (2015) Biological activity of natural sesquiterpenoids containing a Gemdimethylcyclopropane unit. Natural Product Reports 32(8):1236-1248

30. Barretto DA, Vootla SK (2018) GC-MS Analysis of Bioactive compounds and Antimicrobial activity of Cryptococcus rajasthanensis KY627764 Isolated from Bombyx mori Gut microflora. International Journal of Advanced Research 6(3):525-538

31. Vinjamuri S, Achar S (2017) Comparison of phytochemical components in leaves and stems of Exacum bicolor roxb. by GCMS. World Journal of Pharmacy and Pharmaceutical Sciences 6(7):2134

32. Adesalu TA, Temenu TO, Julius ML (2016) Molecular characterization, lipid analysis and GC-MS determination of bioactive compounds identified in a West African strain of the green alga Oedogonium (Chlorophyta). Journal of Pharmacognosy and Phytochemistry 5(6):1-6

\section{Publisher's Note}

Springer Nature remains neutral with regard to jurisdictional claims in published maps and institutional affiliations.

\section{Submit your manuscript to a SpringerOpen ${ }^{\circ}$ journal and benefit from:}

- Convenient online submission

- Rigorous peer review

- Open access: articles freely available online

- High visibility within the field

- Retaining the copyright to your article

Submit your next manuscript at $>$ springeropen.com 